\title{
Retinite por citomegalovirus (CMV) após terapia imunossupressora para vasculite leucocitoclástica
}

\section{Cytomegalovirus (CMV) retinitis after immunossupressive therapy for leukocytoclastic vasculitis}

Carlos Ewerton Maia Rodrigues ${ }^{(1)}$, Cláudia Sarmento Gadelha ${ }^{(1)}$, Christiane Aguiar Nobre(2), Maria Roseli Monteiro Callado ${ }^{(3)}$, Rejane Maria Rodrigues de Abreu Vieira ${ }^{(4)}$, Walber Pinto Vieira ${ }^{(5)}$

\section{RESUMO}

A retinite por citomegalovírus (CMV) é uma doença rara que acomete principalmente pacientes com a síndrome da imunodeficiência adquirida (AIDS). No entanto, outros pacientes imunossuprimidos, como os transplantados, os que estão em uso de quimioterápicos, pacientes com lúpus eritematoso sistêmico (LES) ou em tratamento com drogas imunossupressoras também podem ser acometidos. O quadro clínico caracteriza-se por visão turva, diminuição da acuidade ou alterações de campo visual, geralmente unilateral, podendo ocorrer deslocamento de retina. A perda visual é progressiva, evolui em ritmo variável até a completa amaurose do olho acometido. O presente relato de caso descreve um paciente com vasculite leucocitoclástica grave submetido à terapia com corticoide em dose imunossupressora que evoluiu com glaucoma, panuveíte por CMV, perda da acuidade visual e infecção bacteriana secundária.

Palavras-chave: vasculite leucocitoclástica, imunossupressão, retinite por citomegalovírus.

\section{INTRODUÇÃO}

Retinite por citomegalovírus (CMV) é uma complicação de pacientes infectados pelo vírus da imunodeficiência humana (HIV) em estágio avançado, quando a contagem de CD4 é menor que 50 células $/ \mathrm{mm}^{3}{ }^{1-5}$ Antes do advento da AIDS, a

\begin{abstract}
Cytomegalovirus (CMV) retinitis is a rare disease which mainly affects patients with acquired immunodeficiency syndrome (AIDS). Nevertheless, other immunosuppressed patients, such as the organ transplant recipients, the ones using chemotherapy, patients with systemic lupus erythematosus (SLE) or in treatment with immunosuppressive drugs can also be attacked. The clinical characteristics are blurred vision, decrease of the visual acuity or visual field alterations, generally unilateral, with the possibility of retinal detachment. The visual loss is progressive, evolving in a variable rate until complete amaurosis of the attacked eye. The present case report describes a patient with severe leukocytoclastic vasculitis, submitted to corticosteroid therapy in immunosuppressive doses that evolved with glaucoma, panuveitis by CMV, loss of visual acuity and secondary bacterial infection.
\end{abstract}

Keywords: leukocytoclastic vasculitis, immunosuppression, retinitis by cytomegalovirus.

retinite por CMV em adultos foi observada quase que exclusivamente em pacientes imunossuprimidos iatrogenicamente, incluindo pacientes transplantados, recebendo quimioterapia para neoplasias e pacientes em terapia imunossupressora para desordens autoimunes. ${ }^{6-11} \mathrm{Na}$ literatura médica, há relatos de

Recebido em (Received on) 11/3/2008. Aprovado (Approved), após revisão, em 16/11/08. Declaramos a inexistência de conflitos de interesse (We declare no conflict of interest).

Serviço de Reumatologia do Hospital Geral de Fortaleza (Rheumatology Division of the Hospital Geral de Fortaleza).

1. Médico Residente do Serviço de Reumatologia do Hospital Geral de Fortaleza (HGF).

1. Internal Medicine Resident of the Rheumatology Division of the Hospital Geral de Fortaleza (HGF)

2. Médica Residente do Serviço de Clínica Médica do HGF.

2. Internal Medicine resident of the HGF

3. Doutora em Ciências pela Faculdade de Medicina da USP, São Paulo-SP.

3. Doctor in Sciences by the Faculdade de Medicina da USP, São Paulo-SP

4. Mestre em Reumatologia pela Universidade de São Paulo (USP), Ribeirão Preto-SP.

4. Master in Rheumatology by the Universidade de São Paulo (USP), Ribeirão Preto-SP

5. Chefe do Serviço de Reumatologia do HGF.

5. Head of the Rheumatology Division of the HGF

Endereço para correspondência (Correspondence to): Carlos Ewerton Maia Rodrigues, Rua Doutor Gilberto Studart, 955, apartamento 801, Papicu, Fortaleza

- Ceará. CEP (Zip Code): 60190-750. Tel.: (085) 32657266/(085) 88911796. E-mail:carlosewerton@hotmail.com. 
de proteinúria na coleta de 24 horas; sorologia para CMV reagente (IgM e IgG), Epstein Baar vírus e Herpes vírus 1 IgM não-reagentes e $\mathrm{IgG}$ reagentes; HTLV, toxoplasmose, herpes vírus 2 e varicela zoster não reagentes para IgG e IgM; nova pesquisa de ANCA e as sorologias para hepatites, HIV e VDRL foram não reagentes. $\mathrm{O}$ tratamento ocular tópico foi mantido, com redução paulatina da prednisona oral. A paciente evoluiu com glaucoma (pressão intraocular $=32 \mathrm{mmHg}$ ), regressão progressiva do edema ocular, drenagem espontânea de secreção purulenta do olho acometido sem recuperação visual.

\section{DISCUSSÃO}

A retinite por CMV é tipicamente encontrada em pacientes imunocomprometidos, principalmente em pacientes portadores de HIV. ${ }^{11}$ A literatura descreveu apenas dois casos de retinite por CMV em pacientes imunocompetentes, ambos antes da epidemia da AIDS e da disponibilidade de drogas anti-CMV. ${ }^{18}$ ressaltando a raridade da doença em indivíduos não portadores de HIV.

Visser et al., ${ }^{16}$ estudando pacientes com HIV, observaram que antes do advento da terapia antirretroviral altamente efetiva (HAART), aproximadamente $30 \%$ dos pacientes com AIDS desenvolviam retinite por CMV. Essas taxas declinaram em $75 \%$ após o início da terapia HAART. ${ }^{16}$ Os autores também observaram que a frequência de perda visual, o deslocamento da retina e a mortalidade foram mais baixos nos pacientes tratados com HAART. ${ }^{16}$

O relato de caso em estudo revelou um curso clínico desfavorável de uma paciente jovem, não portadora de HIV, que apresentou retinite por CMV grave após terapia com dose imunossupressora de corticoide para tratamento de vasculite leucocitoclástica refratária. O quadro evoluiu com deslocamento de retina e coroide, glaucoma, amaurose e infecção bacteriana. $\mathrm{O}$ diagnóstico foi confirmado pela sorologia IgM positiva e pela retinografia com alterações sugestivas de infecção por CMV (exsudatos branco-amarelados associados à hemorragia).

Kuo et al. ${ }^{17}$ descreveram 18 casos de retinite por CMV em pacientes HIV negativo que estavam em uso de terapia imunossupressora, subdivididos em quatro categorias: quatro pacientes submetidos ao transplante de medula óssea, seis pacientes transplantados renais ou cardíacos, três pacientes com doenças linfoproliferativas e cinco pacientes com desordens autoimunes. Entre esses pacientes, quatro receberam ciclofosfamida para vasculite necrotizante sistêmica, doença de Behçet, doença pulmonar intersticial e enxerto corneano após injúria química e um paciente recebeu prednisona em dose imunossupressora para anemia hemolítica autoimune. Os 13 pacientes restantes receberam, além do tratamento específico para sua doença de base, corticosteroide em dose imunossupressora. $\mathrm{O}$ tempo médio do diagnóstico de retinite por CMV após iniciar o tratamento da doença de base foi de 12 meses. Nesse estudo, as taxas observadas de perda visual, uveíte recorrente e mortalidade foram similares às taxas correspondentes aos pacientes com HIV tratados com a terapia antirretroviral. Hodge et al. ${ }^{19}$ em seu estudo sobre fatores de risco iatrogênicos para retinite por $\mathrm{CMV}$, concluíram que o uso de corticosteroides representa um importante fator de risco em pacientes gravemente imunocomprometidos com AIDS. Na mesma linha de pesquisa, Gorensek et al., ${ }^{20}$ estudaram os fatores de risco para retinite por CMV em transplantados cardíacos e concluíram que o único preditor significativo de retinite por CMV foi o uso de corticoide. Nesse estudo, os pacientes usavam corticoide em dose imunossupressora com desmame lento, mantendo uma dose média de $20 \mathrm{mg} /$ dia de prednisona.

Com o aumento do número de transplantes de medula óssea e de órgãos sólidos em todo o mundo, e com o uso de terapia imunossupressora nas doenças autoimunes, a incidência de retinite por CMV tem aumentado. ${ }^{11-13} \mathrm{O}$ caso descrito relata a existência da retinite por CMV em pacientes sem infecção por HIV, visto que a maioria dos trabalhos na literatura associam essas patologias.

Apesar de poucos dados na literatura, parece que o uso de imunossupressores, principalmente a ciclofosfamida e o corticosteroide, pode ser fator de risco para retinite por CMV. Achamos ser importante informar a existência dessa grave e rara complicação clínica, principalmente em nosso meio, onde o uso crônico de corticoide é uma prática rotineira, alertando para as consequências irreversíveis se um diagnóstico e tratamento precoces não forem instituídos.

\section{Cytomegalovirus retinitis after immunossuppressive therapy for leukocytoclastic vasculitis}

\section{INTRODUCTION}

Cytomegalovirus (CMV) retinitis is a complication of patients infected with the human immunodeficiency virus (HIV) in advanced stage, when the CD4 counting is lower than 50 cells/ $\mathrm{mm}^{3} .^{1-5}$ Before the advent of AIDS, CMV retinitis in adults was observed almost exclusively in iatrogenicaly immunossu- 
pressed patients, including transplantation patients receiving chemotherapy for malignancies and patients in immunosuppressive therapy for autoimmune disorders. ${ }^{6-11}$ There are a few published series of patients with CMV retinitis without HIV infection. ${ }^{12-15} \mathrm{Clinical}$ manifestations are highly variable, with severe decreased visual acuity, visual field alteration, evolving with retinal detachment and involvement of noble areas like the macula and the optic nerve, to oligosymptomatic forms that compromises peripheral areas of the retina. ${ }^{2}$ Many patients evolve with amaurosis of the attacked eye, even with the adequate treatment, not existing reports of spontaneous resolution. ${ }^{2}$ Systemic symptoms like fever, adynamia, and anorexia are absent or are due to associated conditions. ${ }^{2}$ The diagnosis of the infection by CMV can be confirmed by sorology (IgG e IgM), isolation and detection by polymerase chain reaction, culture or even by methods of direct visualization (fundoscopy which evidences white-yellowish exudates, generally associated with hemorrhage, edema and vascular attenuation). The treatment is based on the use of potent inhibitors of viral DNA polymerase like the ganciclovir. ${ }^{3}$

The purpose of the present study is to describe a rare case of a patient with severe leukocytoclastic vasculitis submitted to therapy with corticosteroids in high dose, which evolved with CMV retinitis, total loss of the visual acuity of the right eye, glaucoma and secondary bacterial infection.

\section{CASE REPORT}

Thirty five years old patient, female, previously healthy: seven months before admission, presented with high fever, arthralgias and purpuric lesions in upper and lower extremities. She was diagnosed with cutaneous vasculitis being medicated with prednisone $5 \mathrm{mg} /$ day. After three months, the symptoms recurred with larger and confluent lesions, forming violaceous plaques, which biopsy suggested leukocytoclastic vasculitis. The antibodies for collagen vascular diseases (ANA, anti-DNA, anti-RNP, anti-Sm, anti-SSA, anti-SSB) and the sorologies for syphilis, hepatitis B and C ad HIV were negative. The patient was submitted to intravenous (IV) metilpredinisolone for three days and maintained with $60 \mathrm{mg} /$ day of prednisone. She evolved with bacterial infection and sepsis. As of her admission in the Hospital Geral de Fortaleza (HGF) she presented cushingoid appearance, erythema, edema, pain and loss of the central visual field in the right eye (Figure 1), without cutaneous lesions, renal or pulmonary compromise; she was on $40 \mathrm{mg}$ of prednisone. The retinography and angiography questioned the presence of vasculitis and evidenced an extended macular exudation area (Figure 2), in addition to a positive antineu- trophil cytoplasmic antibody with titer $1 / 20$ in cytoplasmic pattern (C-ANCA). The ophthalmologic evaluation suggested a possibility of Behçet's Disease, due to a possible hipopion not confirmed in our service, which in its reevaluation found cotton-wool exudates and perivascular hemorrhages, being suggested the possibility of retinitis by CMV. The puncture of the ocular anterior chamber and vitreous didn't identify bacterial and/or fungic infection. Because of the strong possibility of CMV retinitis we initiated ganciclovir, parentheral and ocular antibioticotherapy. The ocular ultrasonography (US) evidenced partial displacement of the retina and choroid, with inflammatory and hemorrhagic process. The orbit tomography showed the right ocular globe with increased dimensions, proptosis and inflammatory process. Laboratory tests showed blood

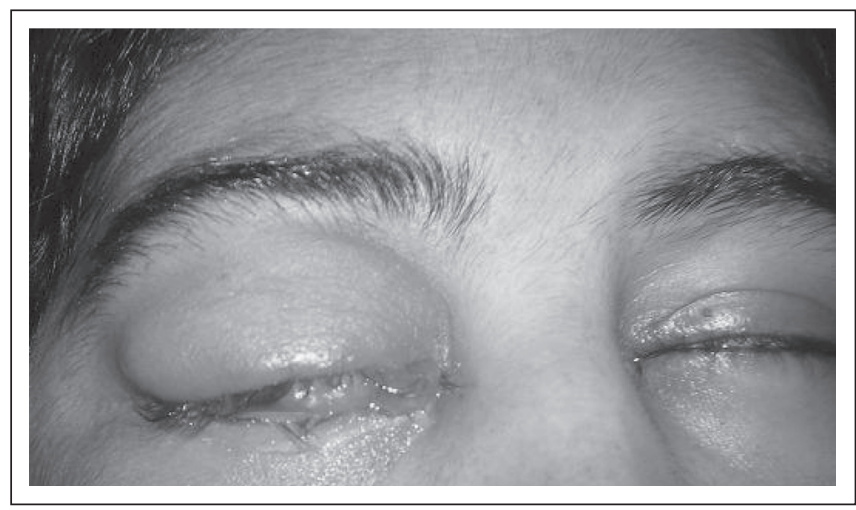

Figure 1. Edema and hyperemia with right ocular proptosis.

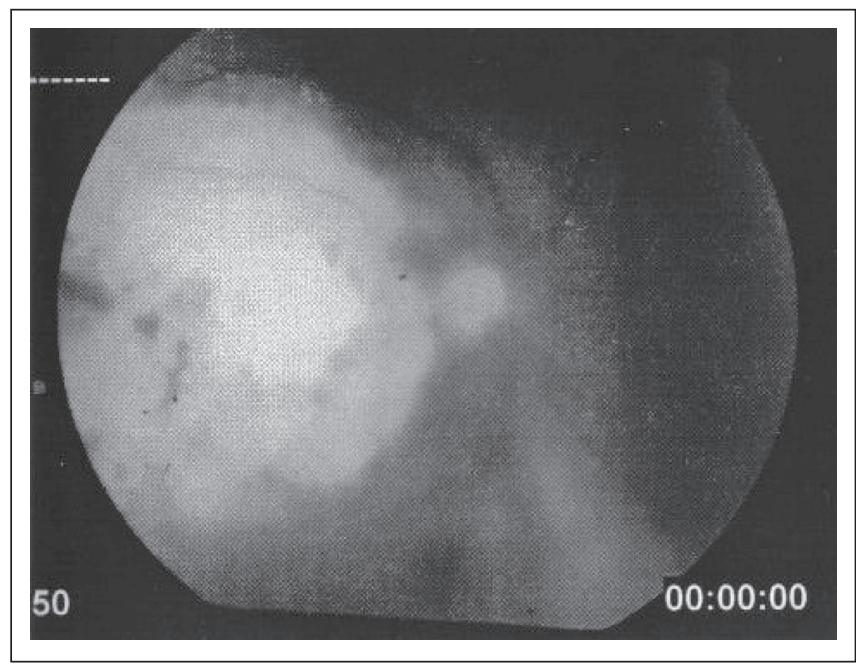

Figure 2. Digital retinography with cotton wool exudates and perivascular hemorrhages. 
count within the normal range, erythrocyte hemosedimentation rate of $82 \mathrm{~mm}, \mathrm{C}$ reactive protein of $62,1 \mathrm{mg} / \mathrm{dL}$, normal C3 and $\mathrm{C} 4$, normal urine summary and absence of proteinuria in the 24 hour collection, Positive IgM and IgG CMV serology, Epstein Baar virus and herpes virus 1 IgM negative and IgG positive; HTLV, toxoplasmosis, herpes virus 2 and varicella zoster negative to IgG and IgM; repeated test for ANCA and the serologies for hepatitis, HIV and VDRL were negative. The topic ocular treatment was kept, with slow tapering of the oral prednisone. The patient evolved with glaucoma (Intraocular pressure $=32 \mathrm{mmHg}$ ), progressive improvement of the ocular edema, spontaneous draining of the purulent secretion of the involved eye without visual recovery.

\section{DISCUSSION}

CMV retinitis is typically found in immunocompromised patients, mainly in patients with HIV. ${ }^{11}$ There are only two published cases of CMV retinitis in immunocompetent patients, both before the AIDS epidemics and the availability of anti-CMV drugs, ${ }^{18}$ highlighting the rarity of the disease in non-HIV individuals.

Visser et al ${ }^{16}$ while studying patients with HIV, observed that before the appearance of the highly effective antiretroviral therapy (HAART), approximately $30 \%$ of the patients with AIDS developed CMV retinitis. These rates declined in $75 \%$ after the beginning of the HAART therapy. ${ }^{16}$ The authors also observed that the frequency of visual loss, retinal detachment and mortality were low in patients treated with HAART. ${ }^{16}$

The case report revealed an unfavorable outcome of a nonHIV young patient, who presented severe CMV retinitis after therapy with immunosuppressive dosage of corticosteroids for treatment of refractory leukocytoclastic vasculitis. The patient evolved with retinal and choroidal detachment, glaucoma, amaurosis and bacterial infection. The diagnosis was firmed by the positive IgM serology and the retinography with suggestive alterations of infection by CMV (white-yellowish exudates associated with hemorrhage).

Kuo et al..${ }^{17}$ described 18 cases of CMV retinitis in patients without HIV who were using immunosuppressive therapy, subdivided in four categories: 4 patients submitted to bone marrow transplant, 6 patients renal or cardiac transplant, 3 patients with linfoproliferative diseases and 5 patients with autoimmune disorders. Among these patients, 4 received cyclophosphamide for systemic necrotizing vasculitis, Behçet's Disease, lung interstitial disease and a corneal graft after chemical injury, and one patient received prednisone in immunosuppressive doses for autoimmune hemolytic anemia.
The last 13 patients received, besides the specific treatment for their disease, corticosteroids in immunosuppressive dose. The average time from starting the treatment to the diagnosis of CMV retinitis was 12 months. In this study, the observed rates of visual loss, recurrent uveitis and mortality were similar to the rates corresponding to the HIV patients treated with the antiretroviral therapy. Hodge et al.,$^{19}$ in his study about iatrogenic risks factors for CMV retinitis, concluded that the use of steroids represent an important risk factor in severely immunocompromised patients with AIDS. In the same research line, Gorensek et al., ${ }^{20}$ studied the risk factors for CMV retinitis in cardiac transplant patients and concluded that the only significative predictor of CMV retinitis was the use of corticosteroids. In this study, the patients used corticosteroids in immunosuppressive dose with slow tapering, keeping an average daily dose of $20 \mathrm{mg}$ of prednisone.

With the increasing number of bone marrow and solid organs transplants all around the world, and the use of immunosuppressive therapy in the autoimmune diseases, the incidence of CMV retinitis has increased. ${ }^{11-13}$ The case described reports the existence of the CMV retinitis in patients without HIV infection, since the majority of the published literature associates these disorders.

Despite the few available data, it seems that the use of immunosuppressors, mainly cyclophosphamide and corticosteroids, can be a risk factor for CMV retinitis. We believe it is important to inform the existence of this serious and rare clinical complication, especially in our community, where the chronic use of corticosteroids is a routine practice, warning of the irreversible consequences if early diagnosis and treatment are not established.

\section{REFERÊNCIAS BIBLIOGRÁFICAS} REFERENCES

1. Kempen JH, Jabs DA, Wilson LA, Dunn JP, West SK, Tonascia JA. Risk of vision loss in patients with cytomegalovirus retinitis and the acquired immune deficiency syndrome. Arch Ophthalmol 2003; 121(4): 466-76.

2. Kempen JH, Jabs DA, Dunn JP, West SK, Tonascia JA. Retinal detachment risk in cytomegalovirus retinitis related to the acquired immunodeficiency syndrome. Arch Ophthalmol 2003; 119(2): 33-40.

3. Jabs DA. Ocular manifestations of HIV infection. Trans Am Ophthalmol Soc 1995; 93: 623-83.

4. Studies of Ocular complications of AIDS Research Group in Collaboration with the AIDS clinical Trials Group. Rhegmatogenous retinal detachment in patients with cytomegalovirus retinitis: foscarnet-ganciclovir cytomegalovirus retinitis trial. Am J Ophthalmol 1997; 124(1):61-70. 
5. Weller TH, Hanshaw JB. Virologic and clinical observations on cytomegalic inclusion disease. New Eng J Med 1962; 266: 1233-44

6. Tufail A, Holland GN. Cytomegalovirus retinitis: are intraocular devices the answer? Br J Ophthalmol 1995;79(12):1066-7.

7. Murray HW, Knox DL, Green WR, Susel RM. Cytomegalovirus in adults. Am J Med 1977; 43: 574-84.

8. Coskuncan JM, Jabs DA, Dunn JP, Haller JA, Green WR, Vogelsang $\mathrm{GB}$, et al. The eye in bone marrow transplantation.VI.Retinal complications. Arch Ophthalmol 1994; 112(3): 372-9.

9. Egbert PR, Polland RB, Gallagher JG, Merigan TC. Cytomegalovirus retinitis in immussupressed hosts: ocular manifestations. Ann Intern Med 1980; 93: 664-70.

10. Jabs DA, Wingard JR, de Bustros S, de Miranda P, Saral R, Santos GW. BW B759U for cytomegalovirus retinitis: intraocular drug penetration. Arch Ophthalmol 1986; 104(10): 1436-7.

11. Maquire AM, Nichols CW, Crooks GW. Visual loss in cytomegalovirus retinitis caused by cistoid macular edema in patients without the acquired immune deficiency syndrome. Ophthalmol 1996; 103: 601-5.

12. Wagle AM, Biswas J, Gospal L, Madhaven JN. Clinical profile and immunological status of cytomegalovirus retinitis in organ transplant recipients. Indian J Ophthalmol 2002; 50: 115-21.
13. Ng P, McCluskey P, McCaughan G, Glanville A, Macdonald P, Keogh A. Ocular complications of heart, lung, and liver transplantation. $\mathrm{Br}$ J Ophthalmol 1998; 82(4): 423-8.

14. Ciardella AP, Barile G, Langton CS. Cytomegalovirus retinitis and FK506. Am J Ophthalmol 2003; 1(36): 386-9.

15. Assi AC, Lightman S. Cytomegalovirus retinitis in patients with Goodpasture Syndrome. Arch Opthalmol 2002; 120: 510-2.

16. Visser L. Managing CMV retinitis in the developing world. Community Eye Health 2003;16(47): 38-9.

17. Kuo IC, Kempen JH, Dunn JP, Vogelsang G, Jabs DA. Clinical Characterisric and outcomes of cytomegalovirus in persons without human immunodeficiency virus infection. Am J Ophthalmol 2004; 138: 341-6.

18. Chawla HB, Ford MJ, Munro JF, Scorgie RE, Watson AR. Ocular involvement in a cytomegalovirus infection in a previously healty adult. Br Med J 1976; 2(6030): 281-2.

19. Hodge WG, Boivin JF, Shapiro SH, Shan KC, Dionne MA. Iatrogenic risk factors for cytomegalovirus retinitis. Can J Ophthalmol 2005; 40: 701-10.

20. Gorensek MJ, Stewart RW, Keys TF, McHenry MC, Goormastic M. A Multivariate analysis of the risk of cytomegalovirus infection in heart transplant recipients. J Infect Dis 1988; 157: 515-22. 